\title{
EFFECT OF SOME PLANT EXTRACTS AND ESSENTIAL OLIS ON CONTROLLING NECK-ROT DISEASE OF ONION. Abo-Elnaga, Heidi I.G. ${ }^{\star}$ and Naglaa G. Ahmed ${ }^{\star \star}$ \\ * Dept. of Plant pathology, Fac. of Agric., Assiut Univ., Assiut, Egypt. \\ ** Institute of Plant Pathology, Agric. Res. Center, Giza, Egypt
}

\begin{abstract}
Onion plant were attacked by neck rot disease caused by Botrytis allii (Munn). The modern trends were directed to study the effect of various natural substance against neck rot disease. The effect of plant extract and essintal oil on the incidence of plant disease was studied. Plant extracts of six plant extracts, clove (Dianthus caryophyllus), cinnamam (Cinnamomum zeylamicum), thyme (Thymus vulgaris L.) fenugreek (Trigonella, fonicum), amme (Ammi visnagal), black pepper (Piper nigrum) and three oil essential gernium (Pelargonium gravedens), black cumin seeds (Nigella sativa L.) and blue gum (Eucalyptus globulus).

The six plant extracts and the three oil essential were evaluated as antifungal substance on the mycelial growth and incidence and disease severity of neck rot disease. The antifungal proprieties of cloves extract was more effective than black pepper then Fenugreek extract on inhibiting mycelial and disease, incidence, while amme, thyme cinnamam showed the lowest effect. On the other hand oil essential of geranium was more effective than blue gum and oil black cummon seeds on inhibiting mycelial growth and disease incidence.

Keywords: Botrytis allii, Plant Extracts and Essential olis.
\end{abstract}

\section{INTRODUCTION}

Onion (Allium cepa. L.) is one of the most economical field crops in Egypt. Neck rot disease caused by Botrytis allii Munn is one of the most serious diseases which attacks onion plants grown for bulb production and during storage. (El-Helaly et al., 1966, Hussein et al., 1977, Maude et al., 1982 and Farrag, Eman 2005). The modren trends are directed to study the effect of various natural substances against some pathogenes causes plant diseases. Medical and aromatic plants as anitifungal substances were also documented (Saksena and Tripathi, 1987; Agha, 1992; Zedan et al., 1994; Sivropoulou et al., 1995). Wilson et al., 1997 tested some plant extracts and essential oils for their antifungal activity against Botrytis allii. The aim of the present work was to study the effect of some plant extracts and some essential oils on controlling neck rot disease of onion.

\section{MATERIALS AND METHODS}

\section{1- Isolation and identification of the causal pathogen:}

Samples of diseased onion plants showing neck rot disease were collected from different localities of Assiut Governorate. Isolation procedures was carried out using infected onion bulbs Giza 6 cultivar. Soaking the infected plant parts in $1 \%$ sodium hypochlorite solution for 10 minutes followed by complete washing in sterile distilled water was used for surface disinfestation of infected sample before plating on PDA medium at $20^{\circ} \mathrm{C}$ for 5-7 days. Pure culture of the developing fungi was obtained by single spore isolat. Primary identification was carried out according to Owen et al., (1950) 
and Barnett (1960) then was confirmed by Assiut University Mycological center (AUMC).

\section{2- Pathogenicity test:}

Apparantly healthy onion bulbs, free from obvious infection by $B$.allii Giza 6 cultivar, were washed thoroughly with tap water, surface sterilized by dipping in $1 \%$ sodiumn hypochlorite solution for 2-3 minutes. Then rewashed with sterile distilled water and left for arial during at room temperature. Inoculum was prepared by growing the three tested isolates on $100 \mathrm{ml}$ Potato Dextrose liqued in $250 \mathrm{ml}$. concical flasks, then incubated at $20^{\circ} \mathrm{C}$. After 6 days incubation culture filtrates were decanted and the growing mycelium of each tested isolate was washed using sterile distilled water, suspended in $100 \mathrm{ml}$ of distilled water and blended in warning blender for two minutes. Healthy onion bulbs were sprayed with the mycelial suspension $4 \times 10^{5}$ propagulus. Fungal suspension was replaced by distilled water and the bulbs were treated in the same manner as a control treatment. Twenty five of bulbs were put in $30 \times 40 \mathrm{~cm}$. Jute sacks for each treatment replicated four times. Sacks were kept in rows at room temperature about $32^{\circ} \mathrm{C}$ for three months. A piece of wet cotton with sterilized distilled water was put in each bag to maintain suitable relative humidity around the bulbs. The percentage of infection were recorded after 3 months and disease index of bulbs were recorded after the end of experiment by using scale of oto 4 was used by AICRIP (1968).

\section{3- Plant extract preperation:}

Plant extracts were prepared from the indicated parts of the following 6 plant species collected from Assuit Government. Buds of clove, stem of cinnamom, thyme (seeds), Amme (seeds) and black pepper (seeds) and fenugreek (seeds).

According to natural medicine these parts of the tested plant were known to have antifingal and or other dermal qualities (Krispel 1986).

Samples were extracted with steril destilled water by autoclaving at $121^{\circ} \mathrm{C}$ for $10 \mathrm{~min}$. The concentration of dried material was $10 \%(\mathrm{w} / \mathrm{v})$. The filtrate was used as test extract as described by Maoz and Neeman (1998).

\section{4- Essential oils extracts:}

Three oils of geranium, blue gum and black cumin at the rat of $1.5 \mathrm{ml} / \mathrm{L}$ were prepared by method described by Baraka et al., (2003).

\section{Effect of some plant extracts on the linear growth of B.allii in vitro.}

The concentration $10 \%$ of clove, black pepper, fenugreek and thymes extracts was prepared by adding suitable amount of sterilized distilled water to the crude extracts of plant $(\mathrm{w} / \mathrm{v})$. One $\mathrm{ml}$ of each tested plant extract were added to 9ml PDA medium in Petri dishes. Inoculation was done with fungal discs, $5 \mathrm{~mm}$ in diameter obtained from B.allii 7 days old culture. Three replicates were used for each tested concentration.

Another group of PDA plates free from plant extracts, inoculated with the fungus as control. All plates were incubated at $20^{\circ} \mathrm{C}$ for 7 days. Linear growth was recorded. The obtained data were statistically analyzed, according to Snedecor and Cochracn, (1967). 


\section{Effect of three essential oils on the Linear growth of B.allii in vitro.}

The concentrations $1.5 \mathrm{ml} /$ Later of gernium, black cumin seeds and blue gum essential olis were prepared by adding suitable amount 0.015 of each tested concentration to 10ml PDA medium in Petri dishes.

Inoculation was done with fungal discs, $(5 \mathrm{~mm})$ in diameter obtained from B.allii 7 days old culture. Three replicates were used for each tested concentration. Another group of PDA plates free from essential oils inoculated with the fungus as control. All plates were incubated at $20^{\circ} \mathrm{C}$ for 7 days. Linear growth was recorded. The percentages of reduction in the mycelial growth were calculated. The obtained data were statistically analyzed, according to Snedecor and Cochracn, (1967).

Effect of plant extracts and essential oil on the disease incidence of neck rot disease during storage:

This experiment was carried out in 2004 and 2005. Two isolates of were used Botrytis allii. Healthy onion bulbs were sprayed with the mycelial suspension $4 \times 10^{5}$ propagulus $/ \mathrm{ml}$ and were soaked in plant extracts all essential oils with the same concentration used in vitro for 5 minutes. The previously treated bulbs were kept in $30 \times 40 \mathrm{~cm}$. Jute sacks each containing 25 bulbs and a piece of wetted cotton to maintain suitable humidity around bulbs. Then kept at room temp. (about $32^{\circ}$ ). Four replicates were used for each treatment a healthy onion bulbs were sprayed with the fungal suspension only used as control. After 90 days from inoculation, percent of infection and disease index of bulbs were recorded after the end of experiment by using scale of 0 to 4 was used by A.I.C.R.I.P. (1968).

Statistical analysis:

The collected data were statistically analyzed using two factor Completely Randomized Block Design. Treatments were compared at 0.05 and 0.01 level of probability L.S.D. (Fisher 1984).

Table (1): Scientific English, and Arabic names of the source used plant extract, Essential oils and their natural component:

\begin{tabular}{|c|c|c|c|}
\hline $\begin{array}{c}\text { Scientific plant extracts } \\
\text { and essential oils }\end{array}$ & English name & Natural component & Arabic name \\
\hline Dianthus caryophyllus & clove & Eugenol & قرنفل \\
\hline Cinnamomum zylanicum & cinnamom & Cuminaldehyde & قرفة \\
\hline Thymus vulgaris, $L$. & thyme & Thymol and carvacrol & زعتر \\
\hline Tigonella fonicum & fenugreek & Tergeneol and Colein & حلبة \\
\hline Ammi visnagal & Khella amme & Khilyen and Glycocid & خله \\
\hline Piper nigrum & black pepper & Pippren Kaloyed & الفلفل الأسود \\
\hline Pelargonium graveolens & geranium & Geraniol & 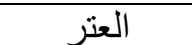 \\
\hline Nigella sativa, $L$. & black cumin seeds & Bachlon & حبة البركة \\
\hline Eucalyptus globulus & $\begin{array}{l}\text { Blue gum } \\
\text { camphor }\end{array}$ & $\begin{array}{c}\text { Cineole } \\
\text { Thynoleycalptus }\end{array}$ & الكافور \\
\hline
\end{tabular}




\section{RESULTS AND DISCUSSION}

Data presented in Table (2) indicated that all isolates of Botrytis allii causes neck rot disease of onion during storge. Data also show that isolate (No.3) was the highly pathogenic followed by isolate (No.2)then isolate (No.3).

These results were in agreement with the finding of El-helaly et al., 1966 and Hussein et al., 1997 Farrag, Eman 2005.

Table (2): Pathogencity test of Botrytis allii isolates causal pathogen of neck rot of onion.

\begin{tabular}{|c|c|c|}
\hline Isolates & Disease incidence \% & Disease severity \% \\
\hline encon & 40 & 32.5 \\
\hline$I_{2}$ & 46 & 37.37 \\
\hline 3 & 54 & 42.25 \\
\hline Control & 0 & 0 \\
\hline L.S.D. & $\begin{array}{l}2.1328 \\
3.0640\end{array}$ & $\begin{array}{l}3.5941 \\
5.1634\end{array}$ \\
\hline
\end{tabular}

Data in Table (3) indicate that all plant extracts inhibited linear growth of Botrytis alli in vitro. compared with control untretd with plant extract. Clove extract was the most active plant extract in inhibiting linear growth of Botrytis alli in vitro followed by, black pepper, feunogrec; amme, cinnamom and thyme subsequently.

Table (3): Effect of plant extracts on the linear growth of Botrytis allii in vitro.

\begin{tabular}{|c|c|c|}
\hline Plant extracts & Isolates & Linear growth (mm) \\
\hline Cloves & $\begin{array}{l}\mathrm{l}_{1} \\
\mathrm{l}_{2}\end{array}$ & $\begin{array}{l}27.5 \\
20\end{array}$ \\
\hline Mean & & 23.75 \\
\hline Cinnamom & $\begin{array}{l}\mathrm{T}_{1} \\
\mathrm{I}_{2} \\
\end{array}$ & $\begin{array}{c}84.1 \\
82 \\
\end{array}$ \\
\hline Mean & & 83.05 \\
\hline Thyme & $\begin{array}{l}\mathrm{I}_{1} \\
\mathrm{I}_{2}\end{array}$ & $\begin{array}{l}85 \\
85\end{array}$ \\
\hline Mean & & 85 \\
\hline Feunogreek & $\begin{array}{l}\mathrm{I}_{1} \\
\mathrm{I}_{2}\end{array}$ & $\begin{array}{c}67.5 \\
60\end{array}$ \\
\hline Mean & & 63.75 \\
\hline Amme & $\begin{array}{l}\mathrm{I}_{1} \\
\mathrm{I}_{2}\end{array}$ & $\begin{array}{l}76 \\
70\end{array}$ \\
\hline Mean & & 73 \\
\hline Black pepper & $\begin{array}{l}\mathrm{I}_{1} \\
\mathrm{I}_{2} \\
\end{array}$ & $\begin{array}{l}57.5 \\
51.6 \\
\end{array}$ \\
\hline Mean & & 54.55 \\
\hline Control & $\begin{array}{l}\mathrm{I}_{1} \\
\mathrm{I}_{2}\end{array}$ & $\begin{array}{l}89 \\
89\end{array}$ \\
\hline Mean & & 89 \\
\hline L.S.D. $\quad 5 \%$ & & $\begin{aligned} \text { I } & 4.430 \\
\text { P } & 8.288 \\
\text { IXP } & 11.720\end{aligned}$ \\
\hline $1 \%$ & & $\begin{array}{cc}\mathrm{I} & 5.976 \\
\mathrm{P} & 11.180 \\
\mathrm{IXP} & 15.810\end{array}$ \\
\hline
\end{tabular}

I Isolates P Plant extracts. IXP Isolates interaction $\times$ Plant extracts. 
The present work is similar to that reported by Nadia and Nasif 2002. He found that clove and eucalyptus oils strongly reduced the mycelial growth of the Macrophomina phaseolina, Fusarium solani, Rhizoctonia solani and Fusarium semitectum. Dawood et al 2003 found that the extract of (Nigella sativa seeds) reduce the dry weight of the Alternaria alternata, Botrytis cinerea, Fusarium oxysporum Fusarium solant, Rhizoctonia solani, Sclerotinia sativa, Sclerotinia bataticola and Sclerotium rolfsii.

Data in Table (4) indicate that all essential oils inhibited linear growth of Botrytis allii in vitro when compared with the control. The most reduction was obtained when geranium was used followed by blue gum then black cumin seeds.

Theses result are agree with Singh and Gupta (1992) and Soltan (1998) essential oils have been recognized as having good fungitoxic Pattnaik et al., (1996) they found that eucalyptus and peppermint oils were effective against Fusarium. solani, Fusarium. oxysporum and M. phaseolina in vitro.

The three essential oil was more effective in isolate 1 than isolate2.

The tested medical and aromatic plants extracts could suppress some plant pathogenic microorganisms due to their activities which include mycelial growth, reduce.

Table (4): Effect of essential oils on the linear growth of Botrytis alli in vitro.

\begin{tabular}{|c|c|c|}
\hline Essential oils & Isolates & Linear growth (mm) \\
\hline Geranium & $\begin{array}{l}\mathrm{I}_{1} \\
\mathrm{l}_{2}\end{array}$ & $\begin{array}{l}50 \\
45\end{array}$ \\
\hline Mean & & 47.5 \\
\hline $\begin{array}{l}\text { Black cumin } \\
\text { seeds }\end{array}$ & $\begin{array}{l}\mathrm{l}_{1} \\
\mathrm{l}_{2}\end{array}$ & $\begin{array}{l}55.8 \\
51.3\end{array}$ \\
\hline Mean & & 53.55 \\
\hline Blue gum & $\begin{array}{l}\mathrm{l}_{1} \\
\mathrm{l}_{2}\end{array}$ & $\begin{array}{c}53 \\
48.3\end{array}$ \\
\hline Mean & & 50.65 \\
\hline Control & $\begin{array}{l}l_{1} \\
l_{2}\end{array}$ & $\begin{array}{l}89 \\
89\end{array}$ \\
\hline Mean & & 89 \\
\hline L.S.D. $\quad 5 \%$ & & $\begin{array}{cc}\mathrm{I} & 1.797 \\
\mathrm{O} & 2.542 \\
\mathrm{IXO} & 3.595\end{array}$ \\
\hline $1 \%$ & & $\begin{array}{cc}\mathrm{I} & 2.479 \\
\mathrm{O} & 3.502 \\
\mathrm{IXO} & 4.953 \\
\end{array}$ \\
\hline
\end{tabular}

I Isolates.

O Essential oil. IXO Isolates interaction $\times$ Essential oil.

Formation and morphological maltformation However, these antimicrobial effects depends on many factors such as chemical structure methods of determination, concentration, plant species, plant age and other biotic (Omar 2000). 
Data presented in Table (5) indicated that the tested plant extracts significantly reduced the effect of the two testing isolates developing of onion neck root disease after 90 days of storage when compared with the control. Plant extracts clove was the most effective treatment in controlling disease incidence and severity through the two tested growing seasons followed by black pepper, fenugreek and thyme respectively.

Table (5): Effect of plant extracts on disease incidence and severity of onion neck-rot after 90 days storage through the growing seasons 2004 and 2005.

\begin{tabular}{|c|c|c|c|c|c|}
\hline \multirow[b]{2}{*}{ Plant extracts } & \multirow[b]{2}{*}{ Isolates } & \multicolumn{2}{|c|}{ Season 2004} & \multicolumn{2}{|c|}{ Season 2005} \\
\hline & & $\begin{array}{c}\text { Disease } \\
\text { incidence }\end{array}$ & $\begin{array}{l}\text { Disease } \\
\text { severity }\end{array}$ & $\begin{array}{c}\text { Disease } \\
\text { incidence }\end{array}$ & $\begin{array}{l}\text { Disease } \\
\text { severity }\end{array}$ \\
\hline Clove & $\begin{array}{l}l_{1} \\
l_{2}\end{array}$ & $\begin{array}{c}99 \\
16\end{array}$ & $\begin{array}{c}8.25 \\
14\end{array}$ & $\begin{array}{l}11 \\
18\end{array}$ & $\begin{array}{c}10.25 \\
14.5\end{array}$ \\
\hline Mean & & 12.5 & 11.12 & 14.5 & 12.37 \\
\hline Thyme & $\begin{array}{l}\mathrm{I}_{1} \\
\mathrm{I}_{2}\end{array}$ & $\begin{array}{l}12 \\
21\end{array}$ & $\begin{array}{l}10.75 \\
17.75\end{array}$ & $\begin{array}{l}14 \\
24 \\
\end{array}$ & $\begin{array}{c}13 \\
20.25\end{array}$ \\
\hline Mean & & 16.5 & 14.25 & 19 & 16.62 \\
\hline Feunogreek & $\begin{array}{l}\mathrm{I}_{1} \\
\mathrm{I}_{2}\end{array}$ & $\begin{array}{l}11 \\
20\end{array}$ & $\begin{array}{c}10 \\
16.5\end{array}$ & $\begin{array}{l}13 \\
23\end{array}$ & $\begin{array}{l}12 \\
19\end{array}$ \\
\hline Mean & & 15.5 & 13.25 & 18 & 15.5 \\
\hline Black pepper & $\begin{array}{l}I_{1} \\
I_{2}\end{array}$ & $\begin{array}{l}10 \\
19\end{array}$ & $\begin{array}{c}9.5 \\
15.5\end{array}$ & $\begin{array}{l}12 \\
22\end{array}$ & $\begin{array}{c}11.25 \\
18.5\end{array}$ \\
\hline Mean & & 14.5 & 12.5 & 17 & 14.87 \\
\hline Control & $\begin{array}{l}\mathrm{I}_{1} \\
\mathrm{I}_{2}\end{array}$ & $\begin{array}{l}40 \\
50\end{array}$ & $\begin{array}{l}32.5 \\
39.5\end{array}$ & $\begin{array}{l}42 \\
54\end{array}$ & $\begin{array}{l}35.25 \\
42.25\end{array}$ \\
\hline Mean & & 45 & 36 & 48 & 38.75 \\
\hline $\begin{array}{l}\text { L.S.D. } \\
5 \%\end{array}$ & & $\begin{array}{cc}\mathrm{I} & 1.827 \\
\mathrm{P} & 2.885 \\
\text { IXP } & 4.085\end{array}$ & $\begin{array}{|cc|}\text { I } & 1.963 \\
\text { P } & 3.104 \\
\text { IXP } & 4.390 \\
\end{array}$ & $\begin{array}{cc}\text { I } & 2.370 \\
\text { P } & 3.747 \\
\text { IXP } & 5.299\end{array}$ & \begin{tabular}{|cc} 
I & 2.456 \\
P & 3.883 \\
IXP & 5.491
\end{tabular} \\
\hline $\begin{array}{l}\text { L.S.D. } \\
1 \%\end{array}$ & & $\begin{array}{cc}\text { I } & 2.460 \\
\text { P } & 3.889 \\
\text { IXP } & 5.500\end{array}$ & $\begin{array}{cc} & 2.644 \\
\mathrm{P} & 4.180 \\
\mathrm{IXP} & 5.912\end{array}$ & $\begin{array}{|cc|}\text { I } & 3.191 \\
\text { P } & 5.046 \\
\text { IXP } & 7.136\end{array}$ & $\begin{array}{cc}\text { I } & 3.307 \\
\text { P } & 5.22 \\
\text { IXP } & 7.394\end{array}$ \\
\hline
\end{tabular}

Role in the ability of black pepper, blue gum in control of Botrytis allii may be attributed to the presence of sterols $\propto$ triterpens, phenolic, glycosides, alkaloids and carbohydrates $\propto$ glycosides, alkaloides and carbohydrates $\propto$ glycosides, anthraquinone, glycosides, tannins, saponin, flavonoids, cardiac, glycosides (Abd El-All, et al., 2003). Effect of thyme extracts may be attributed to the antifungal activity of the natural components, thymoll Muller-Riebau et al., 1995) gallic acid (Cowan, 1999) and phenolic alcohol, polyphenols and flavones (Vokou et al., 1984). Hassanein and El doksch, 1997) reported that thyme, pepper, ment and carawy oils showed high antimicobial activity against Agrobacterium tumefaciens, Pseudomonas solanacearum and Erwinia carotovora in vitro and in vivo. Medicinal plant 
treatments. Akhtar and Mahmood 1996 and Amin, 1999). Finally, it could be of great impact on the future of biotic or and organic farming approach in Egypt treated with some ground plant parts (aromatic and medicinal plants) in order to have clean, save, low cost and toxic free agricultural commodities. It could be concluded that use of natural plant extracts to control fungal plant disease may be extended in the future, instead of fungicides which destroy the material equilibrium and cause sever environmental pollution.

Data presented in Table (6) indicated that natural essential oils tested significantly reduced the development of neck rot disease of onion during the two tested seasons when compared with the control in case of the two tested isolates of Botrytis allii. Geranium showed the most effective treatment in controlling neck rot (disease incidence and severity) through 2004, 2005 seasons followed by blue gum and Black cumin seeds. The obtained data are in agreement with those of Singh and Gupta (1992) and Soltan (1998). The tested essential oils extracts may contain a variety of substances such as a fixed or volatile oils, tannins, glucoside, alkaloids, flavonoids and saponins while could suppress some plant pathogenic microorganisms. medical plant aromatic possess fungicidal activity and may have a potential for the control of post harvest diseases (Prasad and Stadel backer, (1974) and Singh et al., (1980). It is also agree with the obtained data also are in agreement with Baraka et al., 2003 theses which mentioned that majoram (Geranium) at the rate $1.5 \mathrm{ml} / \mathrm{L}$ was the most effective treatment in controlling fruit rots followed by cinnamon and camphor (Blue gum).

Table (6): Effect of essential oils on disease incidence and severity of neck rot disease of onion 90 days, after storage under growing seasons 2004 and 2005.

\begin{tabular}{|c|c|c|c|c|c|}
\hline \multirow[b]{2}{*}{ Essential oil } & \multirow[b]{2}{*}{ Isolates } & \multicolumn{2}{|c|}{ Season 2004} & \multicolumn{2}{|c|}{ Season 2005} \\
\hline & & $\begin{array}{c}\text { Disease } \\
\text { incidence }\end{array}$ & $\begin{array}{l}\text { Disease } \\
\text { severity }\end{array}$ & $\begin{array}{c}\text { Disease } \\
\text { incidence }\end{array}$ & $\begin{array}{l}\text { Disease } \\
\text { severity }\end{array}$ \\
\hline Geranium & $\begin{array}{l}\mathrm{I}_{1} \\
\mathrm{I}_{2}\end{array}$ & $\begin{array}{l}11 \\
14\end{array}$ & $\begin{array}{c}8.75 \\
12\end{array}$ & $\begin{array}{l}13 \\
16\end{array}$ & $\begin{array}{l}10.5 \\
13.7\end{array}$ \\
\hline Mean & & 12.5 & 10.37 & 14.5 & 12.1 \\
\hline $\begin{array}{ll}\text { Black } & \text { cumin } \\
\text { seeds } & \end{array}$ & $\begin{array}{l}\mathrm{I}_{1} \\
\mathrm{I}_{2}\end{array}$ & $\begin{array}{l}15 \\
20\end{array}$ & $\begin{array}{c}13.5 \\
19\end{array}$ & $\begin{array}{l}18 \\
22\end{array}$ & $\begin{array}{c}17 \\
18.5\end{array}$ \\
\hline Mean & & 17.5 & 16.25 & 20 & 17.75 \\
\hline Blue gum & $\begin{array}{l}\mathrm{I}_{1} \\
\mathrm{I}_{2}\end{array}$ & $\begin{array}{l}13 \\
15\end{array}$ & $\begin{array}{c}9 \\
13\end{array}$ & $\begin{array}{l}15 \\
18\end{array}$ & $\begin{array}{c}13.25 \\
16.5\end{array}$ \\
\hline Mean & & 14 & 11 & 16.5 & 14.87 \\
\hline Control & $\begin{array}{l}\mathrm{I}_{1} \\
\mathrm{I}_{2}\end{array}$ & $\begin{array}{l}40 \\
50\end{array}$ & $\begin{array}{l}32.5 \\
39.5\end{array}$ & $\begin{array}{l}42 \\
54\end{array}$ & $\begin{array}{l}32.25 \\
42.25\end{array}$ \\
\hline Mean & & 45 & 36 & 48 & 37.25 \\
\hline L.S.D. & & $\begin{array}{cc}\text { I } & 2.979 \\
\text { O } & 4.213 \\
\text { IXO } & 5.958\end{array}$ & $\begin{array}{cc}\text { I } & 3.055 \\
\text { O } & 4.321 \\
\text { IXO } & 6.110\end{array}$ & $\begin{array}{cc}\text { I } & 3.181 \\
\text { O } & 4.498 \\
\text { IXO } & 6.361\end{array}$ & $\begin{array}{cc}\mathrm{I} & 1.905 \\
\mathrm{O} & 2.698 \\
\mathrm{IXO} & 5.170\end{array}$ \\
\hline L.S.D. & & $\begin{array}{cc}\text { I } & 4.037 \\
\text { O } & 5.709 \\
\text { IXO } & 8.074\end{array}$ & $\begin{array}{cc}\text { I } & 4.140 \\
\text { O } & 5.855 \\
\text { IXO } & 8.251\end{array}$ & $\begin{array}{cc}\text { I } & 4.310 \\
\text { O } & 6.096 \\
\text { IXO } & 8.621\end{array}$ & $\begin{array}{cc}\text { I } & 2.585 \\
\text { O } & 3.656 \\
\text { IXO } & 5.170\end{array}$ \\
\hline
\end{tabular}




\section{REFERENCES}

A.I.C.R.I.P. (1968): Progress Report of the all India coordinated Rice Improvement Project Trials. Agronomy. [C.F. Singh, R.P., and S.C. Mdgal (1978). Influence of different levels of nitrogen on the incidence of bacterial leaf blight in Indica rices. India J. Agron., 174-175].

Abd El-All, S.M.; H.A. Zedan; Fatma, K.K. hidr and A.E. Sanad (2003): Preliminary phytochemial screening separation and identification of certain active components from some plant extracts. J. Agric. Sci. Mansoura Univ., 28 (9): 7025-7042.

Agha, M.S. (1992): Studies on antifungal agents in certain ornamental medicinal and aromatic plants with special reference to control seedlings damping-off disease of seasame. Egypt. J. Appl. Sci., 7 (1): 104-114.

Akhtar, M. and I. Mahmood (1996): Effect of plant based nimin oils on nematodes. Nematologia Mediterrania, 24: 3-5.

Amin, A.W. (1999): Nematicidal activity of some aromatic and medicinial plants in controlling Melidogyne javanica and Helicotylenchus dihstera. Egyptian Journal of Agronematology 31 (1/2): 125-138.

Baraka, M.A.; Fatma, M. Radwan; H.H. Soltan and K.H. Arafat. (2003): Postharvest treatments for controlling persimmon fruit Rats in Cold storage. J.Agric. Sci. Mansoura univ., 28 (5): 4077-4087.

Barnett, H.L. (1960): II lustrated genera of imperfect fungi, $2^{\text {ed }}$ Ed. Burgess publishing company. Minneapolis, U.S.A., 225PP.

Cowan, M.M. (1999): Plant products as antimicrobial agents. Clin. Microbial. Rev., 12 (4): 564-582.

Dawood, K.M.; Y.M. Shabana; El-Sayed A. Fayzalla and El-Sherbiny A.ElSherbny (2003): Search for antifungal compounds of plant origins for biological control of plant diseases. J Agric Sci. Mansoura Univ., 28 (7) 5317-5333.

El-Helaly, A.F., Ibrahim, M.W. Assawah, H.M. Elarosi, M.K. Abo El-Dahab, S.H. Michail, M.A. Abd El-Rehim, E.W. Wasfy M.A. and M.A. ElGoorani (1966): General survey of plant diseases and pathogenic oprganisms in U.A.R. Alex. J.Agric. Res. Bull. 15: 154.

El-Safwani, Nadia A. and O.B. Nasif (2002): Antifungal activity of some plant extracts against damping-off disaease of lupin and chickpea seedlings. J. Agric. Sci. Mansoura Univ., 27 (5): 2945-2953.

Farrage, (Eman), S.H. (2005): Relation of diseases incidence and storability in some Egyptian onion cultivars. Assiut Journal of Agricultural Science, Vol. 36: 29-36.

Fisher, R.A. (1984): Statistical methods for research workers. Oliver and Boy, London.

Hassanein, M., Ferial and H.A. El-Doksch (1997): Antibacterial action of carvone and some plant extracts on certain phytopathogenic bacteria and pathogencity of Agrobacterium tumefaciens. Alex. J. Agric. Res., 42 (1): 127-136. 
Hussein, F.N., Abd El-Razik, F.A. Darwiesh and M.H. Rushdi (1977): Survey of storage diseases of onions and their incitants in Upper Egypt. Egypt J. Phytopathology. 9: 15-23.

Krispel, N. (1986): Medicinal plants: A guide to medicinal plants in Israel. Pressed by krispel.

Maoz, M. and Neeman, I. (1998): Antimicrobial effects of aqueous plant extracts on the fungi microsporum canis and Trichophyton rubrum and on three bacterial species. The society for Applied Microbiology, Letters in Applied Microbiology, 26: 61-63.

Maude, R.B; Bambridge, J.M; Presly, A.H. (1982): The persistence of Botrytis allii in field soil, Plant Pathology Vol. 31 No. 3 PP. 247-252.

Muller-Riebau, F.;B. Berger, and O.Yegen (1995): Chemical composition and fungitoxi properties to phytopathogenic fungi of essential oils of selected aromatic plants growing wild in Turkey. J. Agric. Food. Chem, 43 (8): 2262-2266.

Omar, S.A. (2000): Use of Natural plant products in controlling plant Diseases. Proc. 9th Congress of the Egypt. Phytopathol. Soc., May, Giza, Egypt 416-417.

Owen, J.H., J.G. Walker J.G. and M.A. Stahmann M.A. (1950): Variability in onion neck-rot fungi. Phytopathology, 40: 749-767.

Pattnaik, S., V.R. Subraman and C.Kole (1996): Antibacterial and antifungal activity of ten essential oils in vitro. Microbios, 86 (349): 237-246 (Rev. PI. path. 76(3): 1792, 1997).

Prasad, K. and G.K. Stadelbaker (1974): Effect of acetaldehyde on postharvest decay and market quality of fresh strawberries. Phytpathology, 64: 948.

Saksena, N. and H.S. Tripathi (1987): Oil of anise (Pimpenell anisum L.) Agric and Biol. chim., 51 (7): 1991-1993.

Sendecor, G. W. and W.G. Cochracn (1967): Statistical Methods. Oxford and J.B.H. Publishing Co. $6^{\text {th }}$ edition.

Singh, A.K.; Dickshit, A.; Sharma, M.L. and Dixit, S.N. (1980): Fungitoxic activity of some essential oils. Econ. Bot., 34: 186-190.

Singh, S.P. and K.C. Gupta (1992): Allelopathic effect of some essential oils of plants on Phytopathogenic fungi. Proc. $1^{\text {st }}$ Nat. Symp. Allelopathy in Agroecosystems. Feb 12-14, India. PP. 187-188 (c.f.Rev. PL. Path., 72: 287).

Sivropoulou, A.; S. Kokkini; T. Lanaras and M.Arsenakis (1995): Antimicrobial activity of ment essential oils. J. Agric. Food chem., 43 (9): 2384-2388.

Soltan, H.H.M. (1998): studies on some postharvest diseases of tomato fruits. CRC press, Boca Raton, Florida, 302pp.

Vokou, D.; N.S. Margaris and J.M. Lynch (1984): Effects of volatile oils from aromatic shrubsan soil microorganism. soil Biol. Biochem., 16: 509513.

Wilson, C.L; J.M. Solar; A. El Ghaouth and M.E. Wisniewski (1997): Rapid evalution of plant extracts and essential oils for antifungal activity against Botytis cinerea. J. Plant Disease. 81: 204-210. 
Zedan, A.M., El-Toony A.A. and Awad, N.G.H. (1994): A comparative study on antifungal activity of certain plant extracts, essential oils and fungicides on tomato wilt pathogens. Al-Azhar J. Agric. Res., 20: 217236.

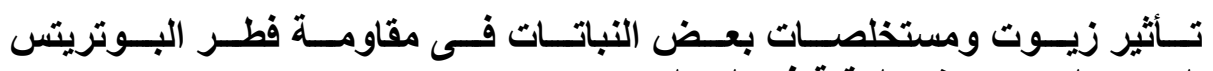

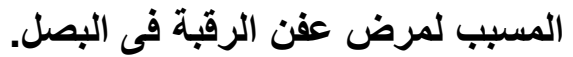

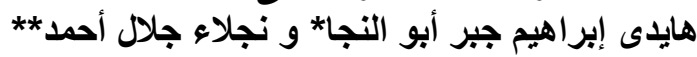

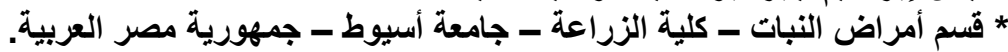

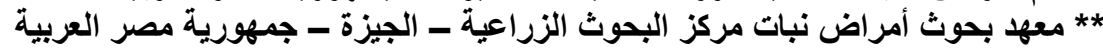

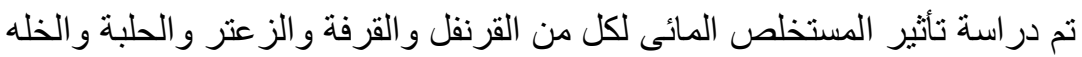

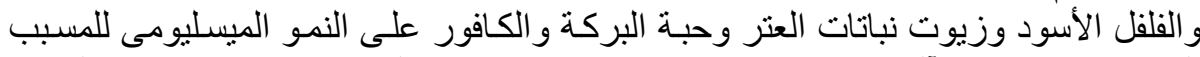

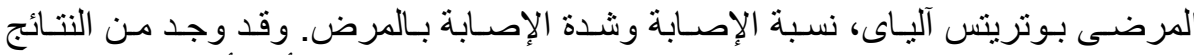

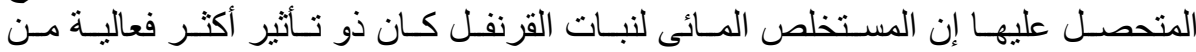

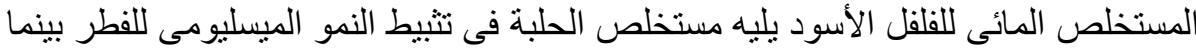

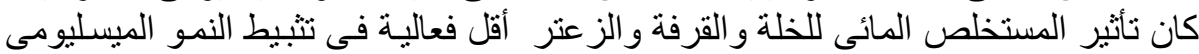

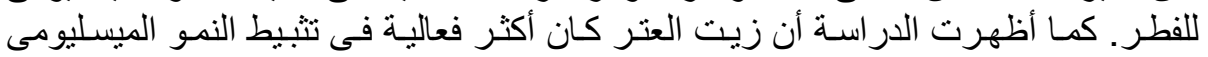

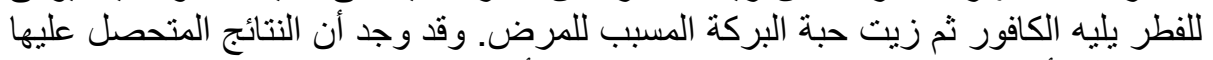

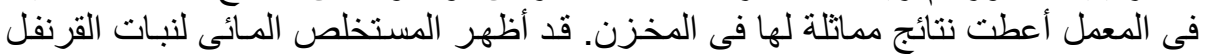

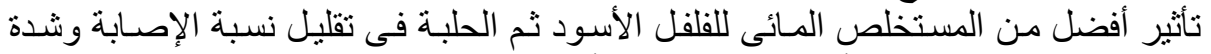

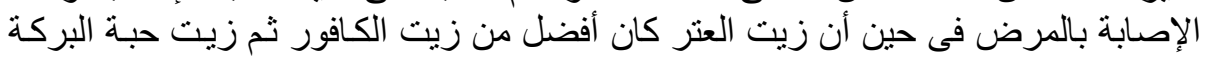

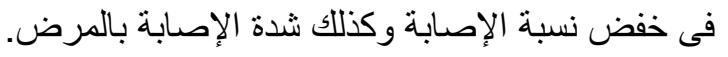

